\title{
Annoyance from environmental tobacco smoke and support for no-smoking policies at eight large Dutch workplaces
}

\author{
Marc C Willemsen, Hein de Vries, Ron Genders
}

\begin{abstract}
Objective - To collect descriptive data on annoyance from environmental tobacco smoke (ETS), attitudes toward smoking at the workplace, and support for a no-smoking policy.

Design - Survey of eight large companies in four sectors of Dutch industry.

Subjects - A representative sample of smoking and non-smoking employees $(n=$ 1480).

Results - Thirty-five per cent of non-smoking employees felt it was "annoying" to "very annoying" when their colleagues smoked during worktime, and $78 \%$ thought a smoky work environment was harmful to their health. About two-thirds of non-smokers "sometimes" to "often" experienced annoyance from ETS at their workplace. The individual solution approach (no explicit policy) is not only rejected by most nonsmokers but also by many smokers. In three sectors of industry, there was much support among employees for a smoking ban except for work areas designated for smoking.

Conclusions - These results could encourage more companies to implement smoking restrictions and they may be used as reference data by companies wanting to develop effective no-smoking policies.
\end{abstract}

(Tobacco Control 1996;5:132-138)

Keywords: environmental tobacco smoke, passive smoking, workplace, smoking policy

\section{Introduction}

Although it has been known for decades that active smoking causes disease in smokers, conclusive evidence that passive smoking is also harmful to health has accumulated more recently. Research has shown that involuntary (passive) smoking is a cause of disease, including respiratory illness and lung cancer. ${ }^{1} \mathrm{~A}$ report of the US Environmental Protection Agency concluded that passive smoking is a known human carcinogen. ${ }^{2}$ The Dutch Institute of Cancer Research has confirmed this conclusion ${ }^{3}$ and the Dutch Health Council has declared that it is very likely that prolonged exposure to environmental tobacco smoke (ETS) increases the risk of lung cancer. ${ }^{4}$ Publications such as these about the harmful health effects of passive smoking have led to measures against smoking in public buildings and workplaces in many developed countries. The best strategy to protect non-smokers' health is tou prohibit smoking altogether or to limie smoking to enclosed, separately ventilated areas, because it is not possible to determine safe exposure levels for carcinogenie substances. $^{2-4}$

In 1989, the European Community adopte a resolution encouraging member states to adopt measures to ban smoking in publiđ places and in all forms of public transport. 9 Many European Union (EU) countries have now implemented such policies for state owned premises. However, with the exception of France, very few countries have provisionso relating to smoking on private premises acces:o sible to the public. ${ }^{6}$ The health dangers of involuntary smoking are much more importane at workplaces than in public places, because of the high frequency and long duration of expo sure to ETS in workplaces. However, the absence of national legislation means that companies still have to be motivated to imple- -3 ment clear non-smoking policies voluntarily? The extent of annoyance from ETS can be one्] important motive for decreasing smoking at the workplace, probably more so than health statistics. In addition to being unpleasant exposure to ETS can cause irritation of then eyes and mucous membranes of the nasal and throat cavity. ${ }^{17}$

An inquiry for the Dutch Foundation of Smoking and Health showed that only $25 \%$ of Dutch worksites took action against ETS ino $1990{ }^{8}$ However, most of these measures were limited to spreading posters to encourage non-음 smoking; only $31 \%$ of these companies imple-⿱ mented bans on smoking. Many employers were reserved regarding smoking bans: No Hearing no complaints about tobacco smoke was the reason most mentioned for deciding not to implement smoking bans. Quite often managers assume there is no annoyance problem, as long as workers do not voice complaintse about ETS. A better strategy would be to asko employees directly about annoyance caused by tobacco smoke and the support for smokingo restrictions. Surveys in the US have shown that most smokers and non-smokers favour restric- $-\frac{\mathbb{D}_{2}}{2}$ tions on smoking at the workplace. ${ }^{9}$ However, few data exist from European countries. This is especially important, because smoking preva-응 lence continues to be higher in Europe than the US. In 1994, smoking prevalence in the EU was $34 \%$ ( $42 \%$ of men and $28 \%$ of women), ${ }^{6}$ compared with less than $26 \%$ in 1990 in the US. ${ }^{10}$ The Netherlands is among the European countries with a high smoking prevalence ( $37 \%$ in 1993 according to one survey ${ }^{11}$ ). 
Another reason for the reservations expressed by companies could be the expectation that insufficient support within the company for smoking bans could lead to social unrest and conflicts at the workplace. However, studies show that measures to reduce smoking (except for a complete smoking ban) have led to very few conflicts or resistance at the workplace. ${ }^{12-16}$ Some studies have shown that support for smoking bans increased after their implementation. ${ }^{17-18}$ There are few studies about the attitudes of European employees toward smoking bans. Implementation of smoking restrictions results in a decrease in annoyance caused by tobacco smoke because of a reduction in tobacco consumption among employees at the worksite. ${ }^{12-25}$ Some research studies show an effect of smoking bans on actual smoking prevalence among employees ${ }^{26-31}$ whereas other studies show no effect. $^{12192023-25}$

This paper presents data from employees in four sectors of industry in the Netherlands on annoyance caused by tobacco smoke at workplaces and on support for measures to reduce worksite smoking. The results may be of interest to health educators and policy makers in countries that may be struggling to implement worksite bans.

\section{Methods}

\section{RESEARCH POPULATION}

Within the framework of a continuing study about the effectiveness of workplace smoking cessation programmes, random samples were taken from employee files of eight large companies. Because the size of the companies varied and we wanted to be able to relate the results to specific companies, a relatively larger sample at the smaller companies was taken: the sample fractions ranged from $10 \%$ at the largest company (3500 employees) to $33 \%$ at the smallest (295 employees). The samples were drawn from files in which all employees were listed in alphabetical order. A sample of $10 \%$, for example, was attained by choosing each 10th person from the list. The same procedure was used in each company.

After an announcement in company newsletters, employees who were in the random sample were approached by telephone for an interview. The interview started with an explanation about the purpose of the interview-namely, to assess employees' opinion about smoking at work-and about the fact that the results would be treated in strict confidence. After agreeing to participate, they were interviewed by means of computerassisted telephonic interviewing (CATI).

The eight companies belong to four sectors of industry: chemistry (1376 employees in two chemical production companies), transport (865 employees in two districts of a bus company), telecommunications (6359 employees in two districts of a telecommunications company), and local government (2318 employees in two mid-sized communities). The current smoking policy for each company was examined by interviewing company representatives and making observations during visits.

\section{MEASUREMENTS}

The following demographic variables were recorded: sex, age, education level, type of


nation), and shift system.

Smoking behaviour was measured by asking whether the respondent smoke $\overline{\bar{B}}$, what was smoked (roll-your-own cigarett manufactured cigarettes, pipe, cigars), and how much was smoked daily and at the workplace.

Attitudes about smoking at the workplace were measured by the following questions: "Does it bother you when smokigg is allowed at the workplace?", "Do you thigh a smokey work environment is harmful to your health?", and "Do you think the chance of gettting cancer for non-smokers is greater when people smoke at the workplace?" The fourth item measured a possible aspect of smoking that is typically Dutch and difficult to translate - namely, whether smoking increases sociability when people are together. A 5-point sciale was used that ranged from completelp agree to completely disagree.

\section{궁}

Annoyance from ETS among ţon-smokers was measured by asking a genefol question: "How often do you experiencE్ annoyance resulting from ETS in your cor 1 pany?" The response choices were: never, sometimes, regularly, often, very often, and alwaæs. Secondly, non-smokers were asked how oftep they found tobacco smoke a nuisance at the and in meeting rooms, canteens, corridors, lifts (elevators), and restrooms.

Both smokers and non-smoker whether they advocated smoking rostrictions in the previously mentioned areas. In addition, they were asked to what extentôtthey agreed with several alternative smoking policies $(-3=$ completely disagree to $3=$ comptetely agree). Four policy options were considêred, varying from no explicit policy to a comptete smoking ban (see table 4). These options correspond to international classifications of polfies for nonsmoking measures. ${ }^{1532}$

STATISTICAL ANALYSES

Differences among the four sectof of industry were analysed with $\chi^{2}$ tests. Muftiple logistic regression analysis was used to assess differences among sectors of ia dustry with regard to employee support for smoking policy options while adjusting for demographic variables and smoking status.

\section{Results}

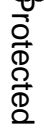

Of 1730 employees who were apgroached for an interview, 1480 interviews were completed. The response rates among the companies ranged from $75 \%$ to $93 \%$ (mean: $=86 \%$ ). $\chi^{2}$ tests were used to compare the sexand age distributions of each sample to data for the full workforce provided by the companies' Departments of Human Resources. These comparisons showed that the samples were representative, with the exception of older 
employees, who were over-represented in the samples of one of the local governments $\left(\chi^{2}(4)\right.$ $=10.5 ; \mathrm{p}<0.05)$ and a telecommunications company $\left(\chi^{2}(4)=20.6 ; p<0.001\right)$.

\section{COMPARISONS AMONG COMPANY TYPES}

The smoking policies in place at the times of the interviews (March to September 1993) differed considerably among the four types of companies, but within each company type they were similar. This also applied to demographic features. Employees did not differ significantly from company to company within the same sector of industry concerning attitudes about smoking at the workplace. Companies within each sector were very also similar regarding company size and type of work. Therefore, this article focuses on differences and similarities among sectors of industry, instead of focusing on differences among individual companies.

\section{DEMOGRAPHIC FEATURES}

Table 1 shows the demographic features of each company type. Respondents in the chemical industry and transport were more likely to be male, to perform manual labour, and to work in shifts, compared with the respondents in the telecommunications sector and those working for the local government. (In the chemical industry respondents usually worked as technicians and operators in the factory, whereas the transport companies employed mainly bus drivers.) The average level of education in the transport industry was lower than in the other types of industry. Respondents from the local government more often had a high level of education (they included different occupations, such as fire workers, social security workers, civil servants, etc.). Common professions in the telecommunications sector were telephone operators, store employees, office employees, and technicians.

\section{SMOKING BEHAVIOUR}

Smoking prevalence did not differ significantly among the industry sectors: on average $34.4 \%$ smoked (table 1). (By comparison, in 1993 between $33 \%$ and $37 \%$ of the Dutch adult population smoked, depending on the survey method used. ${ }^{1133}$ ) Smoking respondents in the

Table 1 Demographic features of each type of company

\begin{tabular}{|c|c|c|c|c|c|}
\hline & $\begin{array}{l}\text { Chemical } \\
\text { industry } \\
(n=391)\end{array}$ & $\begin{array}{l}\text { Telecommun- } \\
\text { ications } \\
(n=506)\end{array}$ & $\begin{array}{l}\text { Transport } \\
(n=198)\end{array}$ & $\begin{array}{l}\text { Local } \\
\text { government } \\
(n=385)\end{array}$ & $\begin{array}{l}\text { All } \\
\text { companies } \\
(n=1480)\end{array}$ \\
\hline Smoker (\%) & 30.2 & 37.0 & 36.0 & 34.0 & 34.4 \\
\hline Male (\%) & 92.1 & 71.3 & 91.9 & $69.9^{\star}$ & 79.2 \\
\hline Mean age $(\mathrm{SD})$ & $41.2(9.1)$ & $39.9(9.3)$ & $41.6(7.9)$ & $39.4(8.7)$ & $40.4(8.9)$ \\
\hline \multicolumn{6}{|l|}{ Type of work (\%) } \\
\hline Manual labour & 38.6 & 15.6 & 41.9 & $17.7^{\star}$ & 25.7 \\
\hline Office work & 22.0 & 10.9 & 48.0 & 13.9 & 19.6 \\
\hline $\begin{array}{l}\text { Combination } \\
\text { manual/office }\end{array}$ & 39.4 & 73.5 & 10.1 & 68.6 & 54.7 \\
\hline \multicolumn{6}{|l|}{ Education level $(\%) \dagger$} \\
\hline Low & 15.1 & 24.4 & 58.6 & $14.5^{\star}$ & 24.0 \\
\hline Medium & 55.1 & 58.5 & 36.9 & 41.9 & 50.3 \\
\hline High & 29.8 & 17.1 & 4.5 & 43.6 & 25.7 \\
\hline Working in shifts (\%) & 40.4 & 12.5 & 85.4 & $9.4^{\star}$ & 28.8 \\
\hline
\end{tabular}

$\star \mathrm{p}<0.001$ ( $\chi^{2}$ tests between four branches).

$\dagger$ Low $=$ primary school, lower vocational training; medium $=$ preparatory school, middle vocational training; high $=$ university, higher vocational training. chemical and transport industry more often consumed roll-your-own cigarettes (versus manufactured cigarettes) $(75 \%$ and $85 \%$ ofo smokers, respectively) than the smoking respondents in the telecommunications sectoro and local government $(51 \%$ and $54 \%$ 范 respectively) $\left(\chi^{2}(3)=39.0 ; \mathrm{p}<0.001\right)$. The prevalence of cigar and pipe smokers did notes differ among the sectors. Between $7 \%$ and $12 \%$ of all smoking respondents smoked cigars and흠 between $3 \%$ and $5 \%$ smoked pipe tobacco $\frac{\bar{m}}{\frac{5}{5}}$ (The percentages add to more than $100 \% \frac{\mathbb{}}{\Omega}$ because some smokers used more then oneon tobacco product.)

The smokers reported an average daily con- $\vec{\circ}$ sumption of 16 pieces of smoking articles (roll- $\vec{\omega}$ your-own cigarettes, manufactured cigarettes, pipe and/or cigars). A one-way analysis of vari- -0 ance showed no significant differences amongiv sectors at the $\mathrm{p}=0.05$ level. About half this $\vec{\omega}$ amount was consumed at the workplace $\left(8.3_{0}^{\mathrm{N}}\right.$ cigarettes). Workplace consumption was 5 significantly lower in the chemical industry $\vec{c}$ than in the telecommunications companies $(7.3$ vs 9.3 cigarettes; $\mathrm{F}(3 ; 501)=3.52 ;$ $\mathrm{p}<0.05)$.

\section{SMOKING POLICY MEASURES}

Interviews with company representatives and personal observations provided details about company smoking policies. All worksites had $a \stackrel{\Omega}{\varnothing}$ moderate smoking restriction - that is, restric- $\overrightarrow{\overrightarrow{0}}$ tions were in place only in specific areas. Sub- 을 stantial differences existed among the four sectors of industry concerning which areas were? smoke-free.

Because of the danger of explosion, smoking was not allowed in the chemical companies at all outdoor premises, in factories, and in laboratories. In addition, smoking was not allowed in two-thirds of the canteens. Furthermore, smoking limitations were operative in controlo rooms, where smoking was allowed only in designated smoking areas. Employees in mosto으 work offices were encouraged to come to mutual agreements about smoking, but no for-음 mal restrictions existed in these offices.

At local governmental worksites, smoking bans were in place in common rooms such as $\tilde{N}$ meeting rooms, corridors, restrooms, lifts, $N$ waiting rooms, and (sections of) canteens. N However, interviews with staff members of one ${ }_{\sigma}^{\omega}$ of the local government organisations revealed that these smoking restrictions were hardly observed, despite a national tobacco law stating that smoking is prohibited in public 0 places, which came into effect in 1990. Little $\vec{P}$ attention was paid to smoking bans, and $\mathbb{C}_{\overparen{Q}}^{\mathbb{Q}}$ restrictions were incompletely identified by $\overrightarrow{\mathbb{Q}}$ posted signs. Thus, for many employees it wasర unclear where smoking was allowed. No restrictions existed in offices.

In the transport companies, smoking restrictions were only operative on buses (the workplace of the drivers). Although violations could lead to sanctions, many drivers still smoked on buses. There were no smoking restrictions for canteens, and employees were allowed to smoke in offices. 
In the telecommunications sector, smoking restrictions existed in rooms with smokesensitive equipment and in small sections of canteens. In almost all other places smoking was allowed, including conference rooms and work offices.

\section{ATTITUDES TOWARD SMOKING IN THE \\ WORKPLACE}

The four sectors did not differ significantly from each other concerning attitudes of non-smokers toward smoking at the workplace. An average of $54 \%$ of the non-smokers claimed to be bothered or very bothered by smoking at the workplace (compared with $7 \%$ of the smokers), $79 \%$ thought a smokey work environment was harmful to their health (compared with $60 \%$ of the smokers), $79 \%$ thought that smoking at the workplace increases sociability when people get together (compared with $25 \%$ of the smokers), and $49 \%$ thought non-smokers had more chance of getting cancer because of smoking at the workplace (compared with $20 \%$ of the smokers).

\section{ANNOYANCE FROM TOBACCO SMOKE}

Table 2 shows how often non-smokers perceived tobacco smoke as annoying at various places in the companies. In all sectors of industry more than two-thirds of non-smokers claimed to be annoyed at least sometimes by ETS in their company as a whole. Depending on the type of sector, the percentage of non-smokers who experienced annoyance in meeting rooms varied from $37 \%$ to $51 \%$, in canteens from $18 \%$ to $62 \%$, in corridors from $11 \%$ to $21 \%$, and in lifts or restrooms from $3 \%$ to $17 \%$.

More employees in the transport sector were annoyed by tobacco smoke in canteens, compared with the other types of companies. On the other hand, respondents from the transport sector experienced significantly less annoyance at their own work office. This is because these employees consider the bus to be their work office. This is in contrast to non-smokers in the telecommunications and government sectors (where $35 \%$ and $38 \%$, respectively, were annoyed by ETS at their work office).

Table 2 Proportion (\%) of non-smoking employees experiencing annoyance from ETS, by industry sector $\dagger$

\begin{tabular}{|c|c|c|c|c|}
\hline Places & $\begin{array}{l}\text { Chemical industry } \\
(n=273)\end{array}$ & $\begin{array}{l}\text { Telecommunications } \\
\text { sector } \\
(n=319)\end{array}$ & $\begin{array}{l}\text { Transport } \\
\text { sector } \\
(n=125)\end{array}$ & $\begin{array}{l}\text { Local } \\
\text { government } \\
(n=254)\end{array}$ \\
\hline $\begin{array}{l}\text { Company as a } \\
\text { whole }\end{array}$ & 69.3 & 71.2 & 67.2 & 67.7 \\
\hline Own work office & 26.4 & 35.1 & 16.8 & $37.8 \star \star \star$ \\
\hline Meeting rooms & 38.8 & 51.4 & 36.8 & $37.0 \star \star \star$ \\
\hline Canteens & 17.6 & 32.9 & 62.4 & $28.3 \star \star \star$ \\
\hline Corridors & 11.0 & 14.4 & 14.4 & $20.5 \star$ \\
\hline Lifts, restrooms $\ddagger$ & 2.9 & 17.2 & 5.7 & $13.3^{\star \star \star}$ \\
\hline
\end{tabular}

† Proportion of non-smokers who are at least sometimes annoyed by ETS at their workplace, based on the question: "How often do you experience annoyance resulting from ETS in your company?" (with answers ranging from never to always).

$¥$ Because answers concerning lifts and restrooms were practically identical, the average from both categories is presented.

$\star$ Differences across sectors significant, $\mathrm{p}<0.05\left(\chi^{2}\right.$ test $)$.

$\star \star \star$ Differences across sectors significant, $\mathrm{p}<0.001$ ( $\chi^{2}$ test)
SUPPORT FOR SMOKING BANS

In all sectors of industry most non-smokers and smokers supported a smodking ban in meeting rooms (table 3). Regardless of company type, a smoking ban far one's own

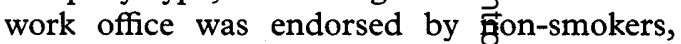
whereas most smokers rejected-this policy. Only in the chemical secto did most non-smokers and smokers suppert a smoking


for smoking bans in corridorg, lifts, and restrooms was lowest in the transigort sector.

Table 4 shows that few mon-smokers favoured the "individual solution ${ }^{3}$ approach in which there is no explicit policy (option 1). Only a bare majority of smokers in the telecommunications and transport sectors supported this policy.

Support for a moderate smoking restriction (smoking bans in public areas onts) (option 2) was significantly higher among noht-smokers in local government than among now-smokers in other sectors. Smokers in loca government were more often in favour of roking bans during meetings (also option 2) Than smokers in the other sectors.

$\overrightarrow{0}$

A policy restricting smoking in.the company except in designated smoking roogis (option 3) was supported more by empleyees in the chemical sector than by employe in the other sectors. In addition, a narrowomajority of smokers and non-smokers in the Eransport and local government sector supporteg this option.

In all company types, the percentage of nonsmoking respondents who were favour of a worksite-wide smoking ban (optiơn 4) was less than $12 \%$.

Table 5 shows odds ratios regression analyses for support ôfor smoking bans in one's own office, for a geteral smoking ban (smoking restricted to desighated areas), and for a complete smoking ban, for each variable of interest, adjusted for all other variables in the table.

Support for a smoking ban one's own office was positively associated with being nonsmoker, being female, and doing shift work. Doing office work was only of minal significance (lower 95\% confidence limit $=1.01$ ). Workers in the telecommunications sector and workers in local government hadng lower odds of supporting bans for one's ownतfffice.

Support for a general smokingban (except in designated areas) was with non-smokers, older employees ${ }^{\prime}>45$ years), office workers, and workers in government and the chemical industry.

Support of a total smoking ban was positively associated with being anon-smoker, being older ( $>45$ years) and doing manual labour. Workers in the chemicalindustry had marginally lower odds of supporthe this policy than workers in the transport secor (95\% confidence interval close to 1 ). ํㅡㄹ.

\section{Discussion}

One important reason why many employers do not impose smoking bans is their perception that employees are not bothered by tobacco 
Table 3 Percentages of employees in each company type in favour of smoking bans in different rooms, by smoking status

\begin{tabular}{|c|c|c|c|c|c|c|c|c|c|c|}
\hline \multirow[b]{2}{*}{ Rooms } & \multicolumn{5}{|c|}{ Non-smokers } & \multicolumn{5}{|c|}{ Smokers } \\
\hline & $\begin{array}{l}\text { Chemical } \\
\text { companies } \\
(n=273)\end{array}$ & $\begin{array}{l}\text { Telecommunications } \\
(n=319)\end{array}$ & $\begin{array}{l}\text { Transport } \\
(n=125)\end{array}$ & $\begin{array}{l}\text { Local government } \\
(n=254)\end{array}$ & $\begin{array}{l}\text { Total } \\
(n=971)\end{array}$ & $\begin{array}{l}\text { Chemical } \\
\text { companies } \\
(n=118)\end{array}$ & $\begin{array}{l}\text { Telecommunications } \\
(n=187)\end{array}$ & $\begin{array}{l}\text { Transport } \\
(n=73)\end{array}$ & $\begin{array}{l}\text { Local } \\
\text { government } \\
(n=131)\end{array}$ & Total 을 \\
\hline $\begin{array}{l}\text { Own work } \\
\text { room }\end{array}$ & 65.2 & 58.6 & 71.2 & 55.1 & 61.2 & 39.0 & 20.9 & 32.9 & $31.3^{\star \star \star}$ & $29.5 \stackrel{=}{\stackrel{\Rightarrow}{\Rightarrow}}$ \\
\hline Meeting rooms & 81.3 & 84.3 & 72.0 & 84.6 & 82.0 & 63.6 & 58.8 & 50.7 & $77.1^{\star \star \star}$ & $63.5 \stackrel{\circ}{\rightarrow}$ \\
\hline Canteens & 68.5 & 35.1 & 44.8 & $54.3^{\star \star \star}$ & 50.8 & 52.5 & 23.0 & 20.5 & $33.6^{\star \star \star}$ & 32.2 응 \\
\hline Corridors & 51.6 & 35.1 & 25.6 & $44.5^{\star \star \star}$ & 41.0 & 60.2 & 47.1 & 38.4 & 64.9 & 53.4 듬 \\
\hline Lifts & 81.7 & 82.4 & 32.8 & $81.5^{\star \star \star}$ & 75.6 & 81.4 & 84.0 & 42.5 & $79.4^{\star \star \star}$ & 76.2 心 \\
\hline Restrooms & 71.4 & 67.4 & 52.0 & $72.0^{\star \star \star}$ & 67.8 & 78.8 & 74.3 & 67.1 & 74.0 & $74.3 \frac{\text { จ }}{\mathrm{\Phi}}$ \\
\hline
\end{tabular}

$\star \star \star$ Differences across sectors significant, $\mathrm{p}<0.001\left(\chi^{2}\right.$ test $)$.

Table 4 Percentage of employees per type of company favouring various smoking policy options, stratified by smoking status

\begin{tabular}{|c|c|c|c|c|c|c|c|c|c|c|}
\hline \multirow[b]{2}{*}{$\begin{array}{l}\text { Non-smoking policy options } \\
\text { (Questionnaire items) }\end{array}$} & \multicolumn{5}{|c|}{ Non-smokers } & \multicolumn{5}{|l|}{ Smokers } \\
\hline & $\begin{array}{l}\text { Chemical } \\
\text { companies } \\
(n=273)\end{array}$ & $\begin{array}{l}\text { Telecommun- } \\
\text { ications } \\
(n=319)\end{array}$ & $\begin{array}{l}\text { Transport } \\
(n=125)\end{array}$ & $\begin{array}{l}\text { Local } \\
\text { government } \\
(n=254)\end{array}$ & $\begin{array}{l}\text { Total } \\
(n=971)\end{array}$ & $\begin{array}{l}\text { Chemical } \\
\text { companies } \\
(n=118)\end{array}$ & $\begin{array}{l}\text { Telecommun- } \\
\text { ications } \\
(n=187)\end{array}$ & $\begin{array}{l}\text { Transport } \\
(n=73)\end{array}$ & $\begin{array}{l}\text { Local } \\
\text { government } \\
(n=131)\end{array}$ & $\begin{array}{l}\text { Tota } \\
(n=\end{array}$ \\
\hline \multicolumn{11}{|l|}{ Option 1: No explicit policy } \\
\hline $\begin{array}{l}\text { 'Employees come to agreements } \\
\text { about where and when smoking is } \\
\text { allowed' }\end{array}$ & 17.6 & 22.9 & 36.0 & $19.7^{\star \star \star}$ & 22.2 & 28.8 & 51.9 & 53.4 & $42.7^{\star \star \star}$ & 44 \\
\hline \multicolumn{11}{|l|}{$\begin{array}{l}\text { Option 2: Moderate smoking } \\
\text { restriction }\end{array}$} \\
\hline $\begin{array}{l}\text { 'For public places, such as corridors, } \\
\text { smoking should be prohibited' }\end{array}$ & 59.3 & 47.6 & 44.8 & $68.1^{\star \star \star}$ & 55.9 & 70.3 & 60.4 & 56.2 & 70.2 & 64 \\
\hline $\begin{array}{l}\text { 'During conferences and other } \\
\text { meetings, employees should not be } \\
\text { allowed to smoke' }\end{array}$ & 89.4 & 89.0 & 83.2 & 91.3 & 89.0 & 77.1 & 67.4 & 61.6 & $86.3^{\star \star \star}$ & 73 \\
\hline \multicolumn{11}{|c|}{ Option 3: General no-smoking policy } \\
\hline $\begin{array}{l}\text { 'Smoking should not be allowed } \\
\text { anywhere in our workplace, except in } \\
\text { designated smoking areas' }\end{array}$ & 79.9 & 65.8 & 65.8 & $68.9^{\star \star \star}$ & 70.5 & 76.3 & 37.4 & 54.8 & $53.4^{\star \star \star}$ & 53 \\
\hline \multicolumn{11}{|l|}{ Option 4: Complete smoking ban } \\
\hline $\begin{array}{l}\text { 'Smoking should be prohibited on all } \\
\text { company premises, without } \\
\text { exceptions' }\end{array}$ & 5.1 & 8.5 & 11.2 & 9.1 & 8.0 & 2.5 & 1.1 & 2.7 & 3.1 & 2.2 \\
\hline
\end{tabular}

$\star \star \star$ Differences across sectors significant, $p<0.001$ ( $\chi^{2}$ test).

Answer choices "completely agree", "agree" and "somewhat agree" were combined into one category ("agree").

+ The two questions covering option 2 were not mutually exclusive.

Table 5 Logistic regression analysis of employees' likelihood of supporting non-smoking policy options ( $n=1480):$ odds ratios and $95 \%$ confidence intervals

\begin{tabular}{|c|c|c|c|}
\hline Variable & Smoking ban in one's own office & General no-smoking policy & Complete smoking ban \\
\hline \multicolumn{4}{|l|}{ Smoking status } \\
\hline Smoker & 1.0 & 1.0 & 1.0 \\
\hline Non-smoker & $3.55(2.79-4.52)^{\star \star \star}$ & $2.25(1.78-2.84)^{\star \star \star}$ & $4.27(2.23-8.14)^{\star \star \star}$ \\
\hline \multicolumn{4}{|l|}{ Age (years) } \\
\hline$<35$ & 1.0 & 1.0 & 1.0 \\
\hline $35-45$ & $1.26(0.95-1.66)$ & $1.18(0.89-1.56)$ & $1.03(0.55-1.90)$ \\
\hline$>45$ & $1.03(0.76-1.39)$ & $1.55(1.14-2.11)^{\star \star}$ & $2.26(1.25-4.11)^{\star \star}$ \\
\hline \multicolumn{4}{|r|}{$2.20(1.25-4.11)$} \\
\hline Female & 1.0 & 1.0 & 1.0 \\
\hline Male & $0.57(0.42-0.77)^{\star \star \star}$ & $0.70(0.52-0.94)$ & $1.06(0.57-1.96)$ \\
\hline \multicolumn{4}{|l|}{ Educational level } \\
\hline Low & 1.0 & 1.0 & 1.0 \\
\hline Medium & $1.23(0.92-1.71)$ & $0.97(0.71-1.32)$ & $1.07(0.59-1.93)$ \\
\hline High & $2.04(1.40-2.99)$ & $0.89(0.61-1.32)$ & $1.28(0.61-2.68)$ \\
\hline \multicolumn{4}{|l|}{ Type of work } \\
\hline Mixed type of work & 1.0 & 1.0 & 1.0 \\
\hline Manual labour & $1.13(0.78-1.62)$ & $1.30(0.90-1.87)$ & $2.17(1.10-4.29)^{\star}$ \\
\hline Office work & $1.37(1.01-1.88)^{\star}$ & $1.82(1.31-2.52)^{\star \star \star}$ & $1.78(0.99-3.23)$ \\
\hline \multicolumn{4}{|l|}{ Shift system } \\
\hline No shifts & 1.0 & 1.0 & 1.0 \\
\hline Shift worker & $2.33(1.69-3.21)^{\star \star \star}$ & $1.41(1.01-1.98)^{\star}$ & $0.61(0.31-1.20)$ \\
\hline \multicolumn{4}{|l|}{ Company type } \\
\hline Transport & 1.0 & 1.0 & 1.0 \\
\hline Chemical industry & $0.65(0.43-0.99)$ & $3.02(1.96-4.65)^{\star \star \star}$ & $0.43(0.19-0.98)^{\star}$ \\
\hline Telecommunications & $0.49(0.31-0.77)^{\star \star}$ & $1.22(0.79-1.89)$ & $0.70(0.30-1.62)$ \\
\hline Local government & $0.42(0.27-0.67)^{\star \star \star}$ & $1.75(1.10-2.77)^{\star}$ & $0.82(0.35-1.92)$ \\
\hline
\end{tabular}

${ }^{\star} \mathrm{p}<0.05 ;{ }^{\star \star} \mathrm{p}<0.01 ;{ }^{\star \star \star} \mathrm{p}<0.001$

smoke at the workplace. ${ }^{8}$ The main conclusion of this study is that annoyance caused by tobacco smoke in various sectors of Dutch industry was considerable. In all sectors, more than $66 \%$ of non-smokers claimed to be bothered by tobacco smoke at the workplace (at least sometimes). This is still lower compared with a Dutch study involving bank employees, in which $80 \%$ were found to be annoyed by ETS. ${ }^{34}$ However, that study was limited by a very low response rate $(29 \%)$, which may have led to an over-representation of employees in the sample who were more often irritated by tobacco smoke. The discomfort reported in 
our study most often occurred in work offices, meeting rooms, and canteens. Seventy-nine per cent of non-smokers thought ETS was harmful to their health.

Strikingly, only $20 \%$ of smokers thought ETS exposure at the workplace would increase non-smokers' chances of getting cancer. In our opinion, health education can and should increase efforts to change this opinion.

Knowledge of current smoking policies in individual companies is important for a thorough understanding of our research findings. As part of the study, interviews with staff members were supplemented with observations during visits. During these visits, notes were taken, but there was no systematic use of checklists to examine the extent to which employees complied with smoking restrictions-for example, whether no-smoking signs were present, the presence of environmental tobacco smoke, or whether ashtrays were around. ${ }^{35}$ Since 1990 Dutch tobacco law asserts that, in state-owned organisations, smoking is prohibited in areas that are accessible to the public. Nevertheless, interviews and observations indicated that there was substantial non-compliance by governmental employees. Employees did not obey the rules and no-smoking signs were not on display. This affirms the findings of inspections conducted in 1994 for the Ministry of Health, Welfare and Sports, which revealed that, in $59 \%$ of Dutch public healthcare institutions, non-smoking signs were displayed only partially or not at all. ${ }^{36}$ Further research is needed to determine the extent to which the tobacco law in general is observed and what determines noncompliance.

With reference to support for smoking restrictions, it was striking that few smokers and few non-smokers favoured the "no explicit policy" option. This finding conflicts with the "common courtesy" solution endorsed by the Dutch tobacco industry as an alternative to policies that restrict or ban smoking. Others have found that the "common courtesy" approach, by itself, is unlikely to substantially reduce exposure to ETS, because most nonsmokers who are bothered by ETS do nothing or simply move away instead of asking smokers to put out their cigarettes. ${ }^{37}$ Only smokers in the telecommunications and transport sectors favoured this laissez-faire option (by a narrow majority). A possible explanation is that these companies had imposed very few restrictions.

Most smokers and non-smokers favoured a smoking ban in meeting rooms, regardless of the type of company they worked for. This suggests that this measure could be implemented in many Dutch companies, and probably in other European companies as well, without significant problems.

Most smokers and non-smokers in the chemical and transportation companies and in local government supported a smoking ban except in designated areas. Through this option, non-smoking is established as the social norm. This policy includes a ban for work areas. A multivariate analysis revealed that support for a general smoking ban (except in designated areas) was greatest with workers in the chemical industry and in governmental worksites. This may be because the policies that were in place in both these sefctors resembled the general no-smoking pslicy: in the chemical industry smoking was not allowed outdoors and designated smoking in several production plants, and in governmental organisations sw⿳⺈⿴囗十 officially restricted to work offices

Cross-sectional data from $\overrightarrow{\mathrm{Q}}$ California survey showed that a moderate smoking restriction (option 2) made no difference compared with no policy at all, but that bans for work areas significantly de tyeased the likelihood of being exposed to ETSS, although not as much as a total ban. ${ }^{38}$ O Our results indicated that the idea of a smoking ban for one's own work offices is welcorted by most non-smokers, but not by smokers (about $30 \%$ ). Support was lowest in telecommunications and governmental worksite $\overrightarrow{\text { and highest }}$ in the transport sector. High supp ing bans among bus drivers can be understood because smoking was prohibited $\overrightarrow{00}$ their place of work (buses).

Studies have shown that employee support for smoking bans increases afer smoking restrictions are introduced. ${ }^{17-18}$ 传 our study, this phenomenon was obsefved crosssectionally. In local government2workplaces, smoking was not allowed in roo accessible to the general public. Ingeed, most governmental employees were in favour of general smoking bans. In the che pinical sector, employee smoking was restrictedfto canteens. Many respondents in this sectod favoured a smoking ban in canteens in तु contrast to respondents in the telecommunications and transport sector, where emplgyees could smoke with few restrictions in car

The results show that employe support for a total smoking ban is extremely low. This may be explained by the Dutch traditional culture of tolerance and respect of individual freedom. However, recent years have seen uch publicity in the Dutch press about smokers becoming "the new social pariahs". This clearly demonstrates that social norms atos smoking are changing. However, in our opinion, support for total bans is still too low to mase it feasible to promote nationwide adoption of complete worksite-wide smoking bans. Indêed, for many European companies the goal of smoke-free workplaces may still be too far in the future. However, if more worksites become smoke-free and their positive experiences are diffused to other worksites, support for comptete smoking bans may increase in European cimpanies. At present in the Netherlands, howewer, there are hardly any worksites to be found that have implemented a complete smoking ban. It will be very difficult for managers to rake employees comply with the ban, as long employee support is so low. In such a situation, the effectiveness of a total ban on workplace smoking will be questionable. Dutch managers currently appear to prefer looking for a consensus solution that fits both smokers' and 
non-smokers' interests. Our data show that the "designated smoking areas" option can garner a fair amount of support from employees. Managers will have to be willing to pay the costs associated with creating designated smoking areas (ideally with separate ventilation systems), as long as support for complete smoking bans has not increased substantially.

For the companies participating in this study, the results have offered compelling reasons to strengthen their smoking policy (a general no-smoking policy instead of a moderate policy). We hope these findings will encourage more large companies to impose smoking restrictions to protect non-smoking employees from ETS exposure. Conditions that favour successful implementation of no-smoking policies in large companies have been described elsewhere. ${ }^{139-41}$ Active management support, the establishment of an executive committee with representatives of employers and employees, and assessment of employee support for no-smoking policy options are all important prerequisites. The questionnaire employed in this study can be used to determine employee support for smoking policy options at workplaces, and the data from different sectors of Dutch industry can be used as reference data for future efforts in the field of workplace smoking policy in countries with high smoking rates similar to those in the Netherlands.

This study was supported by grants from the Dutch Cance Society and the Dutch Heart Foundation.

1 US Department of Health and Human Services. The health consequences of involuntary smoking. A report of the Surgeon General, 1986. Rockville, Maryland: Public Health Service, Centers for Disease Control, 1986. (DHHS Publication No (CDC) 87-8398.)

2 Environmental Protection Agency. Respiratory health effects of passive smoking: lung cancer and other disorders. Washing ton: Office of Health and Environmental Assessment 1992.

3 Jansen DF, Barneveld TA van, Leeuwen FE van. Passief roken en longkanker: het EPA rapport. Amsterdam: Het Nederlands Kankerinstituut, 1993.

4 Health Council [Gezondheidsraad]. Passive smoking: Review of the harmful aspects of environmental tobacco smoke for pubof the harmful aspects of environmental tobacco smoke for pub-
lic health. [Passief roken: beoordeling van de schadelijkheid van omgevingstabaksrook voor de gezondheid.] The Hague: Health Council, 1990

5 Joossens L. Smoking policy in the workplace and other public places. Lung 1990;suppl: 437-44.

6 European Bureau for Action on Smoking Prevention (BASP). Tobacco and health in the European Union: An overview. Brussels: BASP, 1994.

7 Weber A. Annoyance and irritation by passive smoking. Prev Med 1984;13:618-25.

8 Smoking and Health Foundation [Stichting Volksgezondheid en Roken]. Pretest worksite smoking bans: a telephone survey. [Voormeting rookverboden bedriijsleven: een telefonisch onderzoek in opdracht van Stichting Volksgezondheid Roken]. The Hague: Smoking and Health Foundation, 1990.

9 Gallup Organization. Survey of attitudes toward smoking (1985 poll). Princeton, New Jersey: Gallop Organization, 1985.

10 Fiore MC, Newcomb P, McBride P. Natural history and epidemiology of tobacco use and addiction. In: Orlans CT, Slade J, eds. Nicotine addiction: principles and management. New York: Oxford University Press, 1993.

11 Swinkels H. National health survey: aspects of (un)healthy behaviors 1989-1993 [Trendcijfers gezondheidsenquete: aspecten van (on)gezond gedrag, 1989-1993]. Mndber Gezondheid 1994;7:5-14

12 Biener L, Abrams DB, Follick, MJ, Dean L. A comparative evaluation of a restrictive smoking policy in a general hospital. Am f Public Health 1989;79:192-5.
13 Andrews JL. Reducing smoking in the hospital: An effective model program. Chest 1983;84:206-9.

14 Rosenstock IM, Stergachis A, Heaney C. Evaluation of smoking prohibition policy in a health maintenance organization. Am $\mathcal{F}$ Public Health 1986;76:1014-15.

15 Sorensen G, Pechacek T. Implementing nonsmoking policies in the private sector and assessing their effectso New York State f Med 1989;89:11-5.

16 Fielding JE. Smoking control at the workplace. Annu Revō Public Health 1991;12:209-43.

17 Borland $R$, Owen $N$, Hill D, Chapman S. Changes in acceptance of workplace smoking bans following theiff implementation: a prospective study. Prev Med 1990' 19:314-22.

18 Brenner H, Fleischle BMM. Social acceptance of smoking regulations in the workplace. Eur $\mathcal{F}$ Public Healths 1994;4:17-21.

19 Petersen LR, Helgerson SD, Gibbons CM, Calhoud CR尺̊ Ciacco KH, Pitchford KC. Employee smoking behavion changes and attitudes following a restrictive policy or ${ }^{\prime s}$ worksite smoking in a large company. Public Health Rep
1988;103:115-22.

20 Borland R, Chapman S, Owen N, Hill D. Effects of workplace smoking bans on cigarette consumption. $A m$ Æ Public Health 1990;80:178-80.

21 Brenner $\mathrm{H}$, Mielck A. Einschränkungen des Rauchens am Arbeidsplatz und Rauchgewohnheiten: ein Literaturre view. Soz Präventivmed 1992;37:162-7.

22 Brigham J, Gross J, Stitzer ML, Felch LJ. Effects of restricted work-site smoking policy on employees whow smoke. Am ₹ Public Health 1994:84:773-8.

23 Jeffery RW, Kelder SH, Forster JL, French AS, Lando HA으 Baxter JE. Restrictive smoking policies in the workplace: effects on smoking prevalence and cigarette consumption Prev Med 1994;23:78-82.

24 Daughton DM, Andrews CE, Orona CP, Kashinath $\mathrm{D}$ Rennard SI. Total indoor smoking ban and smoking behavior. Prev Med 1992;21:670-6.

25 Gottlieb NH, Eriksen MP, Lovato CY, Weinstein RK, Greenco LW. Impact of a restrictive work site smoking policy on smoking behavior, attitudes, and norms. $f$ Occup Med 1990;32:16-23.

26 Millar WJ. Evaluation of the impact of smoking restrictions in a government work setting. Can $\mathcal{f}$ Public Health 1988;79:379-82

27 Emont SL, Cummings KM. Organizational factors affecting participation in a smoking cessation program and abstinence among 68 auto dealerships. Am $₹ \mathrm{Health}^{\mathrm{O}}$ Promotion 1990;5:102-14.

28 Sorensen G, Rigotti N, Rosen A, Prible R. Effects of a worksite nonsmoking policy: evidence for increased cessation Am F Public Health 1991;81:202-4.

29 Woodruff TJ, Rosbrook B, Pierce J, Glantz SA. Lower levelș of cigarette consumption found in smoke-free workplaces in California. Arch Intern Med 1993;28:1485-93.

30 Stave GM, Jackson GW. Effect of a total work-site smoking ban on employee smoking and attitudes. $\mathcal{F}$ Occup Med 1991;33:884-90.

31 Borland $\mathrm{R}$, Owen $\mathrm{N}$, Hocking $\mathrm{B}$. Changes in smoking behavior after a total workplace smoking ban. Aust $\mathcal{F}$ Public Health 1991;15:130-4.

32 Fisher KJ, Glasgow RE, Terborg JR. Work site smoking ces-0ㅡㅡ sation: a meta-analysis of long-term quit rates from controlled studies. $\mathcal{F}$ Occup Med 1990;32:429-39.

33 Stichting Volksgezondheid en Roken. Faarverslag 1993 [Annual report]. The Hague: Smoking and Health Foun-O dation, 1994.

34 Breteler MHM, Rombouts R. Opinions about smoking bans at the workplace: a review. [Meningen over een rookverbode in de werksituatie: een inventarisatie]. Tijdschr Soc Gezond $=$ heidsz 1986;64:790-3.

35 Rigotti NA, Stoto MA, Bierer MF, Rosen A, Schelling T을 Retail stores' compliance with a city no-smoking law. Am Y Public Health 1993;83:227-32.

36 Ministry of Health, Welfare and Sports. Report on smoking Alkmaar: Keuringsdienst van Waren, 1994

37 Davis RM, Boyd GM, Schoenborn CH. 'CommonN courtesy' and the elimination of passive smoking. Results $\omega$ of the 1987 National Health Interview Survey. $¥ A M A$ 1990;263:2208-10 (erratum published in $¥ A M A$ 1990. 263:3025.)

38 Borland R, Pierce JP, Burns DM, Gilpin E, Johnson M, BaID D. Protection from environmental tobacco smoke in California: The case for a smoke-free workplace. $\mathscr{F} A M A$ 1992; 268:749-52.

39 Fielding JE. Health promotion and disease prevention at the worksite. Annu Rev Public Health;1984:237-65.

40 US Department of Health and Human Services. The healthi consequences of smoking: cancer and chronic lung disease in the workplace. A report of the Surgeon General, 1985. Rockville,
Maryland: Public Health Service, Office on Smoking and Mealth, 1985. (DHHS Publication No (CDC) 85-50207.) 41 Sorensen G, Glasgow RE, Corbett K. Involving work siteso and other organizations. In: Bracht, $\mathrm{N}$, ed. Health promotion at the community level. Newbury Park: Sageso 1990:158-84. 